Article

\title{
Franco-African Relations: No Longer So Exceptional?
}

\section{Tony Chafer}

This is a pre-copy-editing, author-produced PDF of an article accepted for publication in African Affairs following peer review. The definitive publisher-authenticated version Tony Chafer Franco-African Relations: No Longer So Exceptional? Afr Aff (Lond) 2002 101: 343-363. is available online at: http://afraf. oxfordjournals.org/cgi/reprint/101/404/343. 


\title{
FRANCO-AFRICAN RELATIONS: NO LONGER SO EXCEPTIONAL?
}

\author{
TONY CHAFER
}

\begin{abstract}
Key developments in Franco-African relations since 1994 are reviewed. Reservations are expressed about the widely held view that these relations have undergone a process of normalization in recent years and that France is disengaging from its traditional pré carré (sphere of influence) in Black Africa. Instead, it is argued that, under pressure from a rapidly evolving international environment and a changing domestic policy context, a partial modernization of French African policy has taken place. This new global environment has put constraints on French African policy but has also presented France with new opportunities to pursue its national interests in Africa, in the context of globalization and international liberalism. However, certain features of the special relationship remain, such as the role played in Franco-African relations by the réseaux (personal networks). It is therefore concluded that, while a process of adaptation has indeed taken place, Franco-African relations are at present in a period of transition.
\end{abstract}

Franco-African relations have been the subject of considerable debate in recent years, with much of the literature focusing on a perceived shift away from notions of French exceptionalism in its relations with its former Black African colonies towards conceptions of normalisation and even disengagement. The initial focus on exceptionalism was exemplified by a 1981 article in this journal entitled: 'A certain mystery: How can France do everything that it does in Africa and get away with it?', the author of which, Tamar Golan, expressed amazement that 'two decades after independence, this "special relationship" [was] still alive, accepted by and acceptable to both France and the francophones'. Even more surprisingly, she suggested, other countries on the continent - notably Portugal's former colonies - were seeking to get in on the act and join the club. ${ }^{1}$ Golan's work focused on an array of institutional, semi-institutional and informal links constructed prior to, during and after the decolonisation era which underpinned and appeared to consolidate an exceptional relationship featuring special favours and symbolizing the mutual benefits to both France and the governing élites of francophone Africa of a continuing projection of French power and influence in the region. France gained in 'grandeur', thereby underpinning its claim to continue to be considered a world power in the post-colonial era, while African governing élites benefited from a reliable ally that provided economic, political, technical and - if needed - military support, in a situation in which their hold on power was often fragile. Against a background of extreme poverty and social and political divisions within the countries over which they ruled, France represented for them a source of stability.

The more recent notions of normalization have taken as their starting point two significant developments. Firstly, there have been important generational changes, as some of the leading figures in Franco-African relations have died in recent years. The death in 1993 of Houphouët-Boigny, who was the African doyen of the special relationship, was followed by the deaths of François Mitterrand in 1996, Jacques Foccart in 1997 and of the businessman, freemason and arch-fixer Jean-Pierre Prouteau in $1998 .^{2}$ Since a feature of the Franco-African relationship is that it has traditionally been characterized by personal links between African 
political leaders and members of the French governing elites, their disappearance has inevitably had an impact on the special nature of the Franco-African relationship.

Secondly, notions of normalization focus on new and perhaps more attractive areas competing for French attentions in the post-Cold War era, such as eastern and central Europe, south-east Asia and Africa. Commentators have pointed to these new settings for the projection of French power in a globalizing and post-Cold War world, in which Africa is increasingly marginalized from the more dynamic global economic, technological and political currents. ${ }^{3}$ Growing French interest in eastern and central Europe, for example, would be consistent with the central role France wishes to continue to play in European construction as the EU expands eastwards. ${ }^{4}$ One critic of French policy has lamented this apparent loss of French interest in Africa: 'Clearly, France has ceased to consider public development aid and, more generally, its policy of development cooperation, as a central instrument of its foreign policy'. ${ }^{5}$ At the same time, official government spokesmen miss no opportunity to proclaim the 'normalization' of Franco-African relations, while French 'disengagement' from Africa has become a leitmotif of articles by British and American commentators on French African policy. ${ }^{6}$

With these considerations in mind, the aim of this article is to examine the extent to which claims of 'normalization' and 'disengagement' with respect to French African policy are justified. Has the diminution of French ambitions and influence in Black Africa and the redrawing of French interests reached the point where the features of the relationship that traditionally made it 'special' are no longer actually present today? Or alternatively, have the recent changes in French African policy essentially been in the language in which it is couched, formal rather than substantive in nature, affecting the presentation of policy and the institutions charged with its execution rather than policy content? In other words, have the changes been largely cosmetic, so that the underlying reality of Franco-African relations remains 'exceptional', as some have suggested?' ${ }^{7}$ In order to answer these questions, major recent developments in French African policy will be reviewed, together with the changes in the international environment and the internal political pressures which led to these changes being made. In the light of this analysis, the question will then be asked whether a clear policy shift has taken place that lays the basis for a new, more 'normal' French relationship with Black Africa in the future.

\section{Franco-African relations in the post-colonial era: 'I'exception française'}

France's special relationship with Black Africa is based on two pillars: neo-colonialism and the projection of France overseas, the so-called 'besoin de rayonnement'. The latter is a feature of French foreign policy generally and is not therefore limited to Africa. ${ }^{8}$ However, following the traumatic experience of French decolonization in Indochina and Algeria and the consequent loss of French influence in those parts of the world, the maintenance of a 'pré carré' (privileged sphere of influence) in Black Africa became central to France's policy of 'rayonnement'. The origins of this special relationship thus lie in the colonial period, when France emerged as the major colonial power in west and central Africa, and it maintained this relationship into the post-colonial period to provide it with an arena for the projection of French power overseas.

The neo-colonial relationship has traditionally manifested itself at a number of different levels, some institutional, some not. At the institutional level, the Franc zone, which pegged the currency of France's former colonies in Black Africa to the French franc at a fixed rate, and the Ministry of Cooperation, which emerged from the old Ministry for Overseas France and after independence became effectively a ministry for francophone Black Africa, had their roots in the colonial period. The cultural, technical and military cooperation accords which France concluded with its former colonies at independence were a further institutional manifestation 
of this relationship, as were the frequent military interventions that resulted from them. Cultural cooperation served French interests by propagating the French language and culture, while French public development aid reinforced the ties with its African pré carré, maintained dependency and gave privileged access to African markets and raw materials. Just as important, however, were the non-institutionalized forms of the relationship, in particular the close personal links which had been forged between members of the French governing élites and African political leaders under the Fourth Republic. These links have continued into the post-colonial era and are exemplified by the personalized relationships that have existed between French presidents and African political leaders under the Fifth Republic. Moreover, although according to the constitution African policy is the shared responsibility of the president and prime minister, it has in practice formed part of the president's 'domaine réservé' since 1958 and each president has had his own personal adviser on African affairs as part of an Africa 'cell' which operates outside the normal government channels and is not accountable either to the government or parliament.

Other links, such as the annual Franco-African summits which were initiated in 1973 at the instigation of the president of Niger, Hamani Diori, are difficult to classify as they lie somewhere between the institutional and the non-institutional. They are institutionalized to the extent that they bring together French and African political leaders and their officials, but insofar as they do not have any published agenda or make formal policy recommendations, they resemble more informal family gatherings than official inter-governmental meetings. Finally, there is what I call here the Paris-African complex, which has traditionally operated both through official channels and unofficial contacts - the so-called 'réseaux' (networks). ${ }^{9}$ These networks have been one of the main vehicles for the clientelist relations maintained by France with its former African colonies in the post-colonial period. The best known of them was operated by Jacques Foccart, who knew most of the heads of state of the newly independent francophone African states personally. Other significant networks have been those run by the former president's son Jean-Christophe Mitterrand, the 'freemasons' network, the Elf petrol company network and that run by the former interior minister and current president of the Hauts-de-Seine region, Charles Pasqua. A key feature of this complex is that the official and unofficial links have sometimes worked in parallel and sometimes in collusion. For example, its activities have often been 'covered' by high ranking politicians or civil servants in Paris, or it has operated in conjunction with one of France's secret service agencies. One result of this is that the public and private domains have frequently overlapped, so that the distinction between affairs of state and private interests has become blurred. ${ }^{10}$

A corollary of France's 'exceptional' relationship with Black Africa is thus the particular configuration of the institutions and levers of French state power that was necessary to underpin them. However, by the early 1990s, French African policy and the political actors charged with its execution were attracting increasing domestic criticism. This criticism focused in particular on the self-serving and wasteful use of French public development aid, nearly all of which was tied to the purchase of over-priced French goods or the obtaining of contracts for French firms. Aid was also sometimes siphoned off by corrupt regimes that received French support purely because they were friendly to France. ${ }^{11}$ The scale and intensity of such criticism greatly increased after the Rwanda genocide of 1994, French implication in which focused unprecedented media attention on France's African policy.

\section{Recent developments in French policy towards Africa: 1994 as a turning point}

The year 1994 started with the 50\% devaluation of the CFA franc, which had been tied to the French franc at a fixed rate since 1948. The devaluation must be seen alongside the so-called 'Abidjan doctrine', announced by Prime Minister Balladur in September 1993, which 
stipulated that budgetary aid to Franc zone countries would henceforth be conditional upon these countries having previously signed an accord with the International Monetary Fund and the World Bank. ${ }^{12}$ Its effect was to align French aid policy towards Black Africa with the neo-liberal approach to economic policy and structural adjustment of the Bretton Woods institutions. Taken together, these two measures sent a clear message to African political leaders that there would be no more special favours like the bail-outs that Paris had provided in the past to tide them over when the public coffers were bare at the end of the month. Since these special arrangements, together with the fixed CFA exchange rate with the French franc, were regarded by African leaders as one of the pillars of the Franco-African special relationship, the economic as well as symbolic significance of these measures was considerable. To appease African opinion, France could offer little other than short-term budgetary support to ease the transition.

Shortly after this, in April, 800,000 Tutsis and moderate Hutus died in the Rwanda genocide, which was followed in July by Opération Turquoise involving the dispatch of French forces to the south-west of the country in what was to be the last of France's old-style, large scale military interventions in Black Africa. French forces had actually been in Rwanda since 1990, partly to protect French nationals but also to provide support for the Hutu-dominated government of Juvénal Habyarimana, which was coming under threat from the Tutsi-controlled Rwandan Patriotic Front (RPF). Opération Turquoise was justified at the time by the need to create a humanitarian 'safe zone' for refugees from the Rwandan civil war, although its main consequence was to provide a safe haven and escape route into Zaire (now the Democratic Republic of the Congo) for many of those who had been involved in the genocide and were fleeing the advancing forces of the RPF. The latter, led by Rwandan exiles, had entered the country from Uganda and, having defeated the army of the genocidal regime of former president Habyarimana, were in control of most of the rest of the country by the time of Turquoise. French military and logistical support for Habyarimana in the run-up to the genocide and the consequent implication of the French government in preparations for the genocide focused the attention of both international and domestic opinion on French military intervention in Black Africa in a manner that was unprecedented. ${ }^{13}$ From political independence in 1960 to 1994, there had been an average of one French military intervention in Black Africa per year, but these now stopped. The combination of international and domestic criticism of the French role in Rwanda served to de-legitimize overt military intervention as an instrument of policy so that, when the client regime of France's long-standing ally, President Mobutu, was threatened and finally overthrown by Laurent Kabila's armed rebellion in neighbouring Zaire in 1996-7, France did not intervene openly, although covert support for Mobutu was provided in conjunction with one of France's secret service agencies, the Direction de la Surveillance du Territoire. ${ }^{14}$

The French role in Rwanda and Zaire marked an important turning-point for French military policy in Africa. Not only had France received a bloody nose in Rwanda, but also its support for the genocidal regime of Habyarimana and its support to the last of the discredited Mobutu had left France isolated in the international arena. By the time France finally gave up on Mobutu in May 1997, the US and all the other European powers, including the former colonial power Belgium, had abandoned him, and Nelson Mandela had taken on the role of mediator in an effort to avert a civil war between Mobutu's and Kabila's supporters. France by this time had become completely marginalised in Zaire.

It was against this background that a new policy initiative was launched, with a view to replacing old-style military interventions with a different type of intervention. Called RECAMP (Renforcement des Capacités Africaines de Maintien de la Paix), this new French-led peace-keeping programme aimed at enabling Africans to take greater responsibility 
for the maintenance of security and participate more fully in peace-keeping on the continent. The central innovation for France is the 'multilateralization' of military policy, which comprises two elements: the "Africanization" of regional security and a "multinationalization" of western interests exemplified by Franco-British and American-led initiatives to create regional peacekeeping forces'. ${ }^{15}$ This is in France's interest for several reasons. It helps avoid the danger of France becoming militarily and diplomatically isolated and, in the case of a decision to intervene militarily, it shares the responsibilities, risks and financial burden of military intervention. Also, if France is to succeed in making its development aid more effective and in opening up new markets and investment opportunities, this can only happen in the context of greater political and economic instability in Africa.

The idea underlying the plan is that European countries such as France can help to keep the peace in Africa by providing training, transport and equipment for troops, whose deployment is coordinated by Africa's regional organizations. The model for this was the French-sponsored establishment of a Mission Internationale de Surveillance des Accords de Bangui to keep the peace in the Central African Republic following France's decision to withdraw its permanent garrison from the country in $1997 .{ }^{16}$ For Paris, this new approach has the advantage of maintaining influence - and lucrative arms markets - while reducing the attendant political risks and economic costs of unilateral military interventions. At the same time, the contingent of French troops permanently stationed in Africa was reduced from over 8,000 to 5,000, although this was accompanied by measures to improve the projection capabilities of French forces: the aim is that France will in future be able to deploy and sustain up to 60,000 troops and their equipment outside Europe. ${ }^{17}$ This is linked, in turn, to French ideas for the creation of a European defence identity and represents a move towards a European or Euro-Atlantic cooperative framework for future French military actions. ${ }^{18}$

In another initiative which aims at a wider sharing of the responsibility, and risks, of involvement in Black Africa, France has declared a willingness to cooperate more closely with Britain in African policy. The joint Franco-British declaration on co-operation in Africa was launched at the Saint-Malo summit in December 1998. Noting 'the commitment of the British and French governments to work together on international issues in every forum, including the European Union' and 'the special role and the responsibility which the United Kingdom and France ... have in Africa, and their willingness to remain fully engaged there', the declaration committed both governments to harmonize their policies towards Africa, to promote the EU common position on human rights, democratic principles, the rule of law and good governance, and to contribute to the stability of the continent by tackling the debt problem and maintaining a significant level of development assistance. ${ }^{19}$ This might seem a surprising initiative, given the history of competition between the two nations on the continent and the fundamentally different approach to Africa in Britain, which has never linked its presence in Africa to a sense of its global standing in the way that France consistently has since the Second World War. However, it may also be viewed in a different light, as representing an acceptance by both countries that, as medium-sized powers faced with the loss of autonomous world roles, the best way for middle-sized powers to continue to wield influence is through multilateralism. As with the RECAMP initiative, the French aim in pursuing the Franco-British initiative is to share the costs, and risks, of its African policy and in this way to salvage some of the specificity of the Franco-African relationship. However, it is important to emphasize in this context that Franco-British co-operation is confined largely to broad policy declarations and joint diplomatic initiatives, such as the visit by Foreign Secretary Robin Cook and his French counterpart Hubert Védrine to Ghana and Côte d'Ivoire in 1999. Policy co-operation in specific areas on the ground in Africa has been more difficult to achieve. For example, Zimbabwe's president, Robert Mugabe, was welcomed to Paris by President Chirac in 2001, at 
a time when the UK was attempting to garner EU support for sanctions against his regime.

A further important policy change was the decision in 1998 to place the Ministry of Cooperation under the authority of the Ministry of Foreign Affairs. The idea of merging the two ministries had been aired from time to time since the 1960s and various reports had recommended such a merger, but nothing had been done. ${ }^{20}$ Prime Minister Alain Juppé had proposed such a merger in 1996 but it was blocked by President Chirac. ${ }^{21}$ Following the defeat of the right in the 1997 legislative elections, the Socialist Prime Minister, Lionel Jospin, revived the idea. No longer in a position to block it completely, Chirac nonetheless refused to sanction the abolition of the Cooperation Ministry and its absorption by Foreign Affairs: 'rapprochement' was the preferred term. ${ }^{22}$ The merger has nonetheless gone ahead and the decision to retain a minister for cooperation and francophonie with cabinet rank, while merging the staff and services of the two ministries, thus represented a political compromise. At the same time, the notion of 'pays du champ' (privileged area of action), which was rooted in the old notion of a pré carré and encompassed the idea that certain countries enjoyed a special relationship with France and had privileged access to aid, was abolished and replaced by the notion of a 'zone de solidarité prioritaire' (ZSP). Although the ZSP was based initially on the traditional pré carré, the number of countries covered by the zone had risen to 55 by 1998-9. ${ }^{23}$ Since this has happened at a time when the overall French bilateral aid budget is declining year on year, it is inevitable that the amount of aid going to the traditional champ in Africa has declined substantially. ${ }^{24}$ Finally, and significantly given the French espousal of liberal internationalism, the Finance ministry now controls a higher proportion of the French aid budget than the new Foreign Affairs/Cooperation Ministry. ${ }^{25}$ Quite apart from the significant scale of these changes, their symbolic importance for Franco-African relations was also considerable, as African political leaders have traditionally regarded Cooperation as 'their' ministry.

The other major change in African policy since 1994 has been the reduction in the aid budget, which has declined from 47 billion francs (0.64 per cent of GDP) in 1994 to 33.8 billion ( 0.37 per cent of GDP) in 2000. If French aid to its overseas departments and territories is excluded from the figures, this further reduces the 2000 aid budget to 28.9 billion francs (0.32 per cent of GDP). As Daniel Bourmaud has remarked: 'The relative French exception that distinguished France from other comparable powers such as Germany and the United Kingdom in the field of public development aid seems to have passed'. Moreover, the Fonds Spécial de Développement, which was set up to mitigate the social effects of the devaluation of the CFA franc, has been renamed the Fonds Social de Développement and can now be used to help countries outside the Franc zone, and the proportion of the aid budget devoted to bilateral aid, of which the African pré carré has traditionally been the main beneficiary, declined from 75.6 per cent of the total aid budget in 1994, to 64.7 per cent in $2000 .{ }^{26}$ Overall, an increasing proportion of French aid is multilateral, with the European aid budget a key beneficiary: for example, the French contribution to the European Development Fund rose from 4.6 billion francs in 1998 to 8.9 billion in 2000.

\section{The changing international environment in the 1990s}

Changes in the international strategic environment increased external pressures for changes to French African policy during the 1990s. The end of the Cold War was the first of these. French African policy after the Second World War was driven more by national concerns with 'grandeur' and the projection of French power overseas than by Cold War imperatives. The Cold War was nonetheless a crucial part of the backcloth against which French African policy was played out, as it afforded France a strategic 'space' on the world stage in which it could pursue its national foreign policy goals while remaining part of the 
Atlantic alliance. As a member of the latter, it was able to portray itself as the guarantor of Western interests in west and central Africa, while projecting an image of itself to African governments as an 'honest broker' and champion of their interests in an international arena dominated by Cold War concerns. With the end of the Cold War and the consequent decline in the strategic importance of Black Africa, this opportunity was closed and France now had to define its African policy in the context of a new world order dominated by the US as the sole remaining superpower. Through its position in the Bretton Woods institutions, the US has been able broadly to dictate the international policy agenda for Africa, for example with respect to macro-economic policy and economic and political conditionality, with the result that it has exerted considerable, and growing, influence over African countries that were previously part of France's exclusive pré carré. The US also took the diplomatic initiative in brokering settlements of a number of African conflicts in the 1980s and 1990s, for example between Angola and Namibia and between the government and UNITA rebels in Angola. ${ }^{27}$ France has had no choice but to adapt its African policy to this new situation.

Secondly, in the era of colonial empires, power was centred on the nation-state and linked to territorial control and military strength. This continued to be the case well into the post-colonial era in francophone Black Africa, where French military interventions showed that France continued to see itself as 'the guarantor of stability and a hegemonic power' in the region. ${ }^{28}$ However, the accelerating process of economic globalization during the 1990s has meant that global influence is increasingly linked to economic, financial and commercial power and technological advance. In this context, the economic marginalization of Africa, which generates a declining share of world output and where GDP per capita has declined since the 1970s, combined with its strategic marginalization, ${ }^{29}$ has inevitably had an impact on French perceptions of its involvement in the continent: if Africa is economically and strategically marginalized, the political benefits to France of playing a high profile role there are also reduced.

Changes in Africa in the 1990s have also put pressure on France to revise its African policy. The debt crisis, economic failure, increased political instability, a series of intra- and inter-state conflicts and the humanitarian crises that have ensued from these, have rendered involvement in the continent more problematic and, potentially, more costly in both economic and political terms. The transition to multi-partyism in francophone Africa after the end of the Cold War brought new political leaders to power, but in the process increased political tensions and rivalries. ${ }^{30}$ This happened for example in Benin, Mali and Congo-Brazzaville, and later in Côte d'Ivoire and Senegal, while in other countries, such as Rwanda and Zaire, the result was state collapse. France had no choice but to come to terms with these new leaders and, in those cases where the old regimes collapsed, with entirely new political systems. In most cases, these political transitions led to increased political and sometimes ethnic tensions, as in Côte d'Ivoire, while in others such as Zaire and the Congo it led to armed conflict. In this context, France's traditional 'clientelist' relations with favoured African political leaders and governing élites - the so-called 'interlocuteurs valables' - ran the risk of France becoming too closely identified with the losing side in the case of a change of regime or government. This was not the only problem, however. African states' inability to control or contain these new conflicts posed a threat not only to their own internal security but also, if they crossed borders into neighbouring states, to the security of those states as well. France, which was bound to many of the states concerned by bilateral defence and military cooperation agreements, thus risked becoming involved in multiple and escalating conflicts which it was unlikely to be able to resolve. ${ }^{31}$ Events in Rwanda and former Zaire in 1994-7 were a dramatic illustration of this.

European integration and closer cooperation with NATO have made it more difficult for France to play a distinctive, 'exceptional' role in foreign policy. Deepening European 
economic and political integration and a rapprochement with NATO have led to increasing French involvement in multilateral institutions and therefore less possibility of pursuing an independent line in foreign policy. France has actively promoted, and remains committed to, further European integration; it is part of the European monetary union (EMU) and adopted the euro as its currency in 2002. European integration and economic globalization have forced governments to espouse the values of economic and political liberalism. Maintaining competitiveness and meeting the criteria for membership of the EMU means keeping public expenditure low by reducing business costs and lowering personal taxes. This in turn puts pressure on governments to reduce their g16

development aid budgets, or at least to maintain them at a level comparable to those of their competitors, and represents a further constraint on the pursuit of 'independent', national economic and foreign policies. Not only does this make it more difficult for France to maintain an exclusive pré carré in Africa, it also means that the potential economic and political benefits to France of pursuing such a policy are much reduced. Against the background of recurring economic crises and political instability, the potential gains to France in terms of international prestige and an enhanced profile in the global arena from the projection of French power in Black Africa are likely to be outweighed by the economic costs and political risks incurred, as the French experience in Rwanda demonstrated.

Finally, France wants the EU to play a more significant and coherent role, both politically and militarily, in the international arena. At the same time, new threats to European security, notably in the Balkans, and concerns that Germany might increasingly turn its attentions eastwards following German unification have led France to seek a closer relationship with NATO. ${ }^{32}$ The inevitable result of this is to limit its freedom of manoeuvre as an independent foreign policy actor pursuing its national interests through exclusive, bilateral relations with a small number of favoured client states. Indeed, in an increasingly multi-centred, interdependent world, in which the freedom of nation-states to act independently is increasingly circumscribed, such a policy, based on the notion of an exclusive sphere of influence, appears more and more anachronistic.

\section{The domestic policy context}

External pressures, however strong they may appear, are not necessarily sufficient in themselves to bring about a shift in policy. Indeed the initial reaction of policy makers and officials, when confronted with such pressures, may well be a defensive one. ${ }^{33}$ They may adjust their political discourse while seeking in practice to maintain as much as possible of the status quo, particularly if they have some vested interest in its maintenance. This is especially pertinent to an analysis of French African policy because of the way in which personal interests and loyalties have traditionally interlocked with interests of state in Franco-African relations. For a policy shift to occur, the pressures described above need to impinge on the domestic polity in a pressing way. Short of a serious crisis that poses an immediate threat to national security interests, this means that the need for a policy change has to rise up the domestic political agenda, for example through sustained lobbying from civil society and coverage in the national media, which is then mediated via the political opposition, and that the configuration and relative strength of the different political actors involved in the policy making process has to change as a result. This section will examine the extent to which these conditions for a shift in French African policy have been met.

Firstly, economic constraints were an increasingly important consideration. The over-valued exchange rate between the CFA and French franc meant that the cost of providing budgetary support to African countries was rising. Moreover, the need for such support was likely to grow as the primary products on which Franc zone countries depended for the lion's 
share of their export earnings became increasingly uncompetitive in the world market. However, it was only the combination of these economic considerations with a fortuitous combination of political circumstances that brought about an actual policy shift in this area. Houphouët-Boigny died in December 1993: president of Côte d'Ivoire since political independence and doyen of Franco-African relations, he had long resisted devaluation of the CFA franc. ${ }^{34}$ His health failing, President Mitterrand was in the twilight of his political career and, following the defeat of the left in the 1993 legislative elections, was taking a less proactive role in policy making. Finally, and crucially, the defeat in the legislative elections had ushered in a second period of 'cohabitation' between a Socialist president and a right-wing prime minister.

According to the Constitution, responsibility for foreign and defence policy is shared between the president and prime minister, although the exact nature of their respective roles is not made clear. The new prime minister, Edouard Balladur, who was an economic liberal with no particular attachments to, or interest in, Africa, did not share in the mind-set of other Fifth Republic political leaders who conceived of French African policy above all as a political instrument for the projection of French power overseas. His intervention was decisive in pushing France to adopt the 'Abidjan doctrine'. From his perspective, the African link brought no clear, substantial economic benefit to France and, since he did not share in its symbolic value as a pillar of the Franco-African special relationship, there was no rationale for retaining the fixed parity with the French franc. The significance of this change was that external pressures were mediated internally by the arrival of a new political actor with the power and will to make changes. In contrast, a few months later, when the Rwanda tragedy began to unfold, Balladur maintained a low profile, preferring to leave the initiative to the president and the interior minister, Charles Pasqua. This can be explained by the influence wielded over the president by his son and special advisor on African affairs, Jean-Christophe, who had close links with Habyarimana and the old Rwandan governing élite, and the power of Pasqua's 'Corsican network' in sub-Saharan Africa, with its links to the secret services and the Elf petrol company. ${ }^{35}$

A further political reconfiguration of the personnel overseeing African policy took place in 1995, with the election of Jacques Chirac to the presidency and the appointment of Alain Juppé as prime minister. In the context of the Franco-African special relationship, the former is usually seen as a representative of the old guard: 'Jacques Chirac belongs to the galaxy of "Africans", that is to say those who, in the French political class, identify themselves with that distinctively Franco-African relationship that has developed since the beginning of the Fifth Republic'. ${ }^{36}$ Juppé on the other hand was a reformer: he had been foreign minister in the Balladur government of 1993-5; like the prime minister he had no special attachment to Africa and was opposed to the personalized, clientelist nature of the Franco-African relationship; and he was in favour of the 'normalization' of Franco-African relations. However, his key proposal in this regard, for the abolition of the Ministry of Cooperation, was blocked by the president and its implementation had to await a further reconfiguration at the apex of the French state, with the election of Lionel Jospin as prime minister in 1997. Another reformer with no particular stake in the Franco-African relationship, Jospin took advantage of the weakened position of the president following the defeat of the right in the legislative elections of that year to push through the reform that Juppé had wanted.

Internal pressure for reform has also come from another, perhaps unexpected, quarter within the French political establishment. It is true that there have been contradictory signs here, as French military interventions since 1994 - and indeed decisions not to intervene - can be interpreted as attempts by France to maintain stability and influence in its traditional pré carré. The intervention in the Central African Republic in 1996-7 and the non-intervention in 
Congo, which allowed Chirac's friend and long-standing ally of 'la Françafrique', Denis Sassou Nguesso, to return to power in 1997, appear to indicate the continuation of France's long-standing policy of grandeur and the maintenance of stability in its pré carré through military intervention. ${ }^{37}$ On the other hand, there has been no new military intervention on the scale of Opération Turquoise, which mobilized 2500 men in 1994, and there has been a reduction in the French military presence in Africa, with one of its six permanent military bases (Bangui) being closed completely while the other five have been reduced in size. ${ }^{38}$ Several factors have played a role here. International criticism of the French military role in Rwanda has undoubtedly been a consideration. ${ }^{39}$ In an increasingly unstable political situation, the large military presence, especially in major urban centres which are often the focus for political protest, carries the risk of the French military being drawn into conflicts which it cannot resolve. In this context, the succession of mutinies by soldiers of the Central African army from April 1996 onwards was the key factor in the decision to withdraw from Bangui. ${ }^{40}$ Furthermore, some African states have become more critical of what they see as an increasingly anachronistic military presence, so that the political returns France can expect to obtain from its interventions in Africa are reduced. Thus, although budgetary considerations have been given as the main reason for the reduced military presence, strategic and military considerations have also played a role.

However, French African policy cannot be judged simply by its official manifestations. Smith and Glaser have documented how France's military networks operating in support of favoured African clients have remained active and how they continue to be driven by the so-called Fashoda syndrome. ${ }^{41}$ More recently, arms sales have been organized to several countries, including Angola, and mercenaries have been recruited for Congo-Brazzaville, apparently through the good offices of Alfred Sirven, Elf's financial director. ${ }^{42}$

Nonetheless, the increased 'visibility' of Franco-African relations since 1994 has created complications for the Paris-African complex. Public awareness of the corrupt practices that have been a feature of French African policy has increased: Stephen Smith's articles in Libération, Patrick de Saint-Exupéry's in Le Figaro, revelations contained in the parliamentary commission of enquiry on French involvement in Rwanda, which have been reproduced widely in the media, and Philippe Lemayrie's articles in Le Monde diplomatique, have given African policy higher political prominence within France. Moreover, NGOs, which have traditionally played a much less prominent role in France with respect to African policy than their counterparts in Britain, have become more active since 1994: the work of Agir ici, Survie and the Observatoire Permanent de la Coopération Française have played an important role in this respect.

Most important in terms of putting pressure on the Paris-African complex has been the succession of legal investigations into the affairs of prominent figures in France's various African networks: former cooperation minister Michel Roussin, former interior minister Charles Pasqua, former presidential adviser to his father on African affairs, Jean-Christophe Mitterrand, and directors of the Elf petrol company have all come under investigation. Roussin and Mitterrand spent several nights in gaol before being bailed and Alfred Sirven, Elf's director of finance in the 1980s and 1990s and recently extradited with some difficulty from the Philippines, remains in detention. ${ }^{43}$ Roussin, who is also a former colonel in one of France's secret service agencies, the Direction Générale de la Sécurité Etrangère, is currently head of the employers' federation Africa committee and a vice-president of Bolloré, a vast holding company run by Vincent Bolloré with extensive interests in Africa in transport, ports, tobacco, wood, cocoa, rubber and cotton. ${ }^{44}$ He was a close aide to Jacques Chirac as mayor of Paris in the 1980s and early 1990s and has played a key role in fund-raising for his party, the neo-Gaullist Rassemblement pour la République. These activities are now under investigation. 
As for Mitterrand junior, he has been linked, together with Charles Pasqua, to money laundering activities and illegal arms sales to Angola. ${ }^{45}$ These investigations, together with the much-publicized failed lawsuit for 'offence to a foreign head of state' brought against François-Xavier Verschave by three African heads of state, have placed French African policy and the illicit activities of France's African networks under the media spotlight. ${ }^{46}$

\section{Towards a new African strategy?}

We have seen above that there have been significant changes in Franco-African relations since the mid-1990s, in response to growing international and domestic pressures. Demands for a change in policy were not in fact new. A series of reports since the 1960s had advocated a new approach to Franco-African relations. ${ }^{47}$ However, the first significant sign that French African policy might be about to change came in 1990 at the La Baule Franco-African summit when, with the tide of democracy unfurling over east and central Europe, President Mitterrand announced that French aid would henceforth be linked to democratization. ${ }^{48}$ Shortly afterwards, the government also promised debt reduction to middle-income countries engaged in the democratization process. ${ }^{49}$ However, although France suspended development aid to Zaire (1991) and Togo (1993) and provided logistical support for elections in Benin (1990), the Central African Republic (1992) and Niger (1993), it rapidly became clear that France was backtracking on its commitment to democratization. Not only did President Mitterrand announce at the 1991 Francophonie summit that each country should 'set the terms and pace of its own reform', it also became clear that France was not prepared to reward countries engaged in the democratization process at the expense of traditional allies who were not. For example, Benin, which democratized, saw its aid reduced from 580 million francs in 1989 to 300 million in 1990, while Togo, which remained an authoritarian regime, received more aid in 1990 (923 million francs) than it had the previous year (628 million). ${ }^{50}$ Because of the traditionally pre-eminent role that the president plays in French African policy, the La Baule announcement did seem to presage a change of direction for Franco-African relations. However, the balance sheet of the new policy of 'Paristroika', as it was dubbed at the time, was at best mixed: since 1992, French 'aid to institutional development', as it is called, has in practice given priority to security concerns and the re-establishment of the authority of the state over democratization. ${ }^{51}$

At the same time, economic pressures on French African policy were growing. The 'strong franc' policy, which involved pegging the exchange rate to the German mark, the devaluation of the dollar in the mid-1980s, deteriorating terms of trade between the Franc zone and the rest of the world, the worsening economic crisis in Africa and the growing cost of bailing out bankrupt former colonies, forced France to devalue the CFA franc in 1994, leading to what some commentators have described as a normalization of policy. ${ }^{52}$ However, another way of interpreting this policy shift is as a move by 'modernizers' in Paris to reduce the financial cost of its African policy so as to enable France better to remain. ${ }^{53}$ In this respect, while the devaluation represents an essential adaptation to new realities, it does not necessarily have to be seen as representing a move towards the 'normalization' of Franco-African relations. Rather, it can be interpreted as representing a compromise that enabled France to embrace new realities while preserving as much as possible of the 'old' order of things.

Other policy initiatives in the 1990s can be viewed in a similar light. The half-hearted embracing of political conditionality after La Baule, followed by the whole-hearted adoption of economic conditionality under the 'Abidjan doctrine', the RECAMP initiative, the reform of the Cooperation ministry, the channelling of an increasing proportion of French aid through the European Union and the Saint-Malo declaration, can all be seen at one level as part of a move away from the old policy of the pré carré and thus as part of a process of normalization. On the 
other hand, they can be seen as elements of a wider move towards multilateralism in French African policy, the aim of which is to share the costs, risks and responsibilities of its African presence and involvement. A recent example of this risk-sharing was the joint mission by the French foreign affairs minister, Hubert Védrine, and the British foreign secretary, Jack Straw, to the Great Lakes region in January $2002 .^{54}$ One advantage for France of pursuing this approach is that it frees France's hand to pursue its special relationship with favoured clients such as Gabon, Cameroun, Burkina Faso and Togo, thereby enabling it to preserve something of the Franco-African special relationship. It is an approach that offers something to both the 'traditionalists' and the 'modernizers' in Franco-African relations.

Moreover, government spokesmen have sent out mixed signals since the mid-1990s. For example, the Prime Minister, Lionel Jospin, declared on the one hand that he wanted 'not to do less but to do better' in Africa, while on the other he claimed, in his speech to the South African parliament in May 2001, that he wanted to put an end to the special relationship between France and its traditional pré carré and open up France's African policy to the whole of the continent. ${ }^{55}$ At the same time, the foreign minister, Hubert Védrine, is said to have little interest in Africa and it seems that the present government does not have the political will to pursue an energetic African policy. ${ }^{56}$

This lack of a specific vision of Franco-African relations, together with the new official discourse of 'normalization', can be seen as serving the interests of the Paris-African complex insofar as one of its consequences is to distract attention from the continuing specificities of the Franco-African relationship. The réseaux have not disappeared and in some areas appear to be as active as ever, although they are not necessarily associated with the pursuit of the interests of the state in the same way as they were in the past. In fact, Smith and Glaser have suggested that the réseaux have fragmented, become 'privatized' and have transformed themselves into private 'lobbies that pursue their own objectives, whether or not these objectives implicate the state'. ${ }^{57}$ They also continue to operate with the connivance of France's secret service agencies and the president's Africa cell, and have been able to mobilize substantial financial, diplomatic and military resources in support of their objectives. Moreover, French companies continue to make a good profit from the import-export trade and French business has done well out of the privatization of formerly state-controlled marketing boards and public services in francophone Black Africa. ${ }^{58}$ Many of these companies are well linked with the Paris-African complex, which in this way has found a new means of exercising its influence. In a new world order that is dominated by the ideology of international liberalism, is less state-centred and in which economic, financial and commercial clout have assumed increased importance in the exercise of global power, this may well be an effective way of maintaining French influence in Africa. Indeed, the strength of this new approach may well lie precisely in its combination of these 'modern' power forms with old-style political and military support in Paris.

However, an alternative interpretation is to suggest that the disappearance of the Cooperation ministry and the move to distribute French bilateral aid outside the traditional champ mark the end of the old-style neo-colonial relationship. It can be argued that these changes, together with the fragmentation of the réseaux and the other developments outlined above, have reduced the Paris-African complex's direct political influence over African policy. In cutting the ground from under the Paris-African complex, which largely relied on French bilateral aid for its survival, these changes can be seen as indicative of a clear shift in French African policy. The besoin de rayonnement is still there, and is reflected in continuing efforts in Paris to project French language and culture through La Francophonie and to 'marquer la différence' in the international arena, but the new international environment makes this much more difficult than in the past.

For the moment, it appears that the Jospin government decided that the political risks of 
challenging these lobbies and the complex of interests which they represent are outweighed by any likely political advantage that the government might gain from such a challenge. In a political context of 'cohabitation', such a challenge would have been fraught with danger. If Jacques Chirac had lost the 2002 presidential election, this situation could have changed and the Paris-African complex may well have found official diplomatic and military support for its projects less forthcoming. However, even Chirac is not an unconditional supporter of 'la Françafrique'. Although the principal actors of the Paris-African complex continue to consider him as one of 'theirs', Daniel Bourmaud has pointed out that his stance on African policy is actually pragmatic and deliberately ambiguous, as he has hitherto backed both 'traditionalists' and 'modernizers' in French African policy. ${ }^{59}$ For the time being, therefore, it appears safest to conclude that Franco-African relations are in a period of transition: there has been a process of normalization, but France has not disengaged. To be sure, the relationship is not as distinctive as it was in the past, but it continues to contain some residual special features that can hardly be described as 'normal'.

Tony Chafer is Professor of Contemporary French Area Studies at the University of Portsmouth (UK). He has written widely on Franco-African relations in the colonial and post-colonial period and is the author of The End of Empire in French West Africa. France's Successful Decolonization? (Berg, 2002).

\section{Notes and references}

The author wishes to thank Paul McVeigh and Richard Moncrieff for their comments on an earlier draft of this article.

1. T. Golan, in African Affairs 80 (1981), p. 3.

2. For a profile of the latter, see S. Smith and A. Glaser, Ces Messieurs Afrique. Le Paris-village du continent noir (Paris, Calmann-Lévy, 1992), pp. 9-27.

3. W. Kühne, 'The changing international environment of African politics', in S. Brüne, J. Betz and W. Kühne, eds., Africa and Europe: Relations of Two Continents in Transition (Hamburg, Lit Verlag, 1994), pp. 1-19.

4. It is worth noting, however, that reports of French economic interest in Africa declining as French trade with, and investment in, east and central Europe have grown, appear exaggerated, see C. Gulvin, 'The French economy and the end of the Cold War', in T. Chafer and B. Jenkins, eds., France. From the Cold War to the New World Order (Basingstoke, Macmillan, 1996), pp. 115-25.

5. D. Bourmaud, 'L'aide publique au développement en 1998: les moyens de la fin?' in Observatoire Permanent de la Coopération Française (OPCF), Rapport 1998 (Paris, Karthala, 1998), p. 22.

6. For example, Charles Josselin, Minister for Cooperation, stated in a recent interview that: 'The decision to make the Foreign Affairs ministry responsible for the administration of French 
cooperation policy aimed to put an end to "la Françafrique", Ouest-France, 15 January 2001, quoted in Billets d'Afrique 89 (2001), p. 5. Recent articles in the English language press that take up the theme of normalization include 'France's fading affair with Africa', The Economist, 22 April 1989, pp. 67-8; 'Paris will demote its ties with African backyard', International Herald Tribune, 7 February 1998. Cf. also J. Derrick, 'Generally, one can say that today francophone states' ties with France are no longer distinctive, no longer a cause for suspicion among other African states as they were before', in 'French and African culture', West Africa, 8-14 October 2001, p. 18.

7. X. Renou, 'A new French policy for Africa?', Journal of Contemporary African Studies 20, 1 (2002), p. 24.

8. Cf. P. Cerny, The Politics of Grandeur: ideological aspects of De Gaulle’s foreign policy (Cambridge University Press, 1980).

9. Steven Smith and Antoine Glaser define a 'réseau' as follows: 'An informal, indeed secret, association of individuals, some of whom are civil servants, who pursue common objectives, the realization of which implicates the State and, ultimately, the Nation or some other high idea', in Ces Messieurs Afrique 2. Des réseaux aux lobbys (Calmann-Lévy, 1997), p. 25.

10. The réseaux and their leading figures are documented in Smith and Glaser, Ces Messieurs Afrique and Ces Messieurs Afrique 2. It is worth noting here that these different networks frequently overlap but are also often in competition with each other.

11. C. Freud, Quelle coopération? Un bilan de l'aide au développement Karthala, 1988); J. Adda and M.-C. Smouts, La France face au sud. Le miroir brisé (Paris, Karthala, 1989) and S. Brunel, Le Gaspillage de l'aide publique (Paris, Seuil, 1993). See also G. Cumming, 'Modernisation without "banalisation”: towards a new era in French African aid relations?', Modern and Contemporary France 8, 3 (2000), pp. 360-1.

12. Edouard Balladur's letter to Franc zone heads of state laying out the new policy was published in Le Monde, 23 September 1993.

13. Cf. P. de Saint-Exupéry’s series of articles, 'Quatre ans après le génocide rwandais', in $L e$ Figaro, 30 March-7 April 1998. See also Agir ici/Survie, Les Dossiers noirs de la politique africaine de la France, no. 1 à 5 (Paris, L’Harmattan, 1995), pp. 16-18 and report by the Mission d'information parlementaire sur le rôle joué par la France au Rwanda de 1990 à 1994, summarized in Le Monde, 17 December 1998.

14. The Foccart and Pasqua networks were able to mobilize substantial financial resources to promote the rehabilitation of the Mobutu regime in the US and organized arms sales and the dispatch of mercenaries to support Mobutu's failing regime, see Smith and Glaser, Ces Messieurs Afrique 2, pp. 49-52 and F.-X. Verschave, La Françafrique. Le plus long scandale de la République (Paris, Stock, 1998), pp. 255-65.

15. S. Gregory, 'The French military in Africa: past and present', African Affairs 99 (2000), p. 
442.

16. 'The new foreign legion', Africa Confidential, 18 May 2001, p. 1.

17. Gregory, 'The French military in Africa’, pp. 447-8.

18. J. Bryant, 'Changing circumstances, changing policies? The 1994 Defence White Paper and beyond', in T. Chafer and B. Jenkins, eds., France, pp. 85-6; R. Utley, "Not to do less but do better...” French military policy in Africa’, International Affairs 78, 1 (2002), p. 134.

19. Foreign and Commonwealth Office briefing paper, Saint-Malo summit, 3-4 December 1998.

20. For example in March 1974 the Foreign Minister, Michel Jobert, announced that the Ministry of Cooperation would be abolished and its services merged with the Foreign Ministry. However, on winning the presidential election two months later, Giscard d'Estaing overturned the proposal and reinstated a full Ministry of Cooperation, see J. Chipman, French Power in Africa (Oxford, Blackwell, 1989), p. 200.

21. Refusing to 'banaliser' French African policy, Chirac had actually announced at the 1995 Francophone summit in Cotonou that the Cooperation Ministry would retain its independence, Le Monde, 3-4 December 1995.

22. C. Wauthier, in 'La coopération entre ravalement et réforme', Le Monde diplomatique, March 1998, p. 21.

23. G. Cumming, Aid to Africa. French and British policies from the Cold War to the New Millennium (Aldershot, Ashgate, 2001), p. 409.

24. D. Bourmaud, 'L'aide publique au développement en 2000. Le syndrome du dédoublement’, OPCF, Rapport 2000 (Paris, Karthala, 2000), pp. 26-7.

25. Ibid., p. 23.

26. Ibid, pp. 20-1. For a commentary on the downward trend in the French aid budget, see also http://www.senat.fr: 'Projet de loi de finances pour 2002 - Tome III: Aide au développement' and 'Projet de loi de finances pour 2001, adopté par l'Assemblée nationale - Tome IV, Analyse synthétique’ [accessed 27 March 2002].

27. D. Rothchild, 'The United States and Conflict Management in Africa', in J. W. Harbeson and D. Rothchild, eds., Africa in World Politics, 2nd ed. (Boulder, Co., Westview Press, 1995), pp. 222-6 and Rothchild, 'The Impact of US Disengagement', in Harbeson and Rothchild, eds., Africa in World Politics, 3rd ed. (2000), pp. 171-4. 
28. S. Brüne, 'Under Pressure for Reform: French Policies South of the Sahara', in Brüne, Betz, and Kühne, eds., Africa and Europe, p. 56.

29. T. M. Callaghy, 'Africa and the World Political Economy: More Caught Between a Rock and a Hard Place', in Harbeson and Rothchild, eds., Africa in World Politics, 3rd ed., p. 44.

30. Cf. C. Fomunyoh, 'Democratisation in fits and starts', Journal of Democracy, 12, 3 (2001), pp. 37-50.

31. J.-F. Bayart, 'Fin de partie au sud du Sahara. La politique africaine de la France', p. 120, in S. Michailof, La France et l'Afrique. Vade-mecum pour un nouveau voyage (Paris, Karthala, 1993).

32. J. Bryant, 'France and NATO from 1966 to Kosovo: Coming Full Circle?', European Security, 9, 3, 2000, pp. 26-7; A. Menon, 'From independence to cooperation: France, NATO and European Security’, International Affairs, 71, 1 (1995), pp. 25-32.

33. For a discussion of the ways in which changes in the international environment feed through into policy, see Cumming, Aid to Africa, chapter 6.

34. P. Lemayrie, 'Monnaie dévaluée, peuples oubliés’, Le Monde diplomatique, March 1994, p. 24.

35. Smith and Glaser, Ces Messieurs Afrique 2, pp. 205-31.

36. D. Bourmaud, 'La politique africaine de Jacques Chirac: les anciens contre les modernes', Modern and Contemporary France, NS4, 4, 1996, p. 435. See also Agir Ici-Survie, Dossiers noirs de la politique africaine de la France, no. 6: Jacques Chirac et la Françafrique (Paris, L’Harmattan, 1995).

37. The term 'la Françafrique' was originally coined by Ivoirian president Félix Houphouët-Boigny to describe the special nature of the Franco-African relationship. In its modern sense, referring to the illicit and often corrupt nature of Franco-African relations, it was first used in the newsletter Billets d'Afrique, no.5, in 1994, and has since been used in the title of two works by François-Xavier Verschave to describe what I call in this article the Paris-African complex. The works are La Françafrique. Le plus long scandale de la République (Paris, Stock, 1998) and Noir Silence. Qui arrêtera la Françafrique? (Paris, Eds. Les Arènes, 2000).

38. 'La France remanie son dispositif militaire en Afrique' and 'La France fermera progressivement ses bases en Centrafrique’, Le Monde, 21 July and 2 August 1997. 
39. 'Hunting lobby’, Africa Confidential, 27 July 2001, p. 6.

40. Smith and Glaser, Ces Messieurs Afrique 2, pp. 88-9.

41. Smith and Glaser, Ces Messieurs Afrique 2, pp. 65-93. The 'Fashoda syndrome' refers to a military stand-off between British and French forces in Sudan in 1898, which resulted in the withdrawal of the latter. The term is used today to refer to French fear of an 'Anglo-Saxon' threat to its African pré carré.

42. Billets d'Afrique 88 (supplement) (2001), pp. 2-3; 91 (2001), p. 6, and F.-X. Verschave, Noir Silence, pp. 33-5.

43. 'Presidential pranks', Africa Confidential, 8 December 2000, p. 8 and 'Oil slick', Africa Confidential, 21 December 2001, p. 8.

44. See Agir ici-Survie, Dossiers noirs, no. 15. Bolloré: Monopoles, services compris (Paris, L’Harmattan, 2000); F.-X. Verschave, Noir Silence, pp. 396-403.

45. 'Presidential pranks', p. 8.

46. The court case is related in full in F.-X. Verschave and L. Beccaria, Noir Procès. Offense à chefs d'état (Paris, Eds. Les Arènes, 2001).

47. Cf. the Jeanneney (1964), Gorse (1971), Abelin (1975) and Hessel (1990) reports.

48. 'M. Mitterrand lie l'octroi de l'aide française aux efforts de démocratisation', Le Monde, 22 June 1990.

49. G. Cumming, 'French Development assistance to Africa: Towards a new agenda?', African Affairs 94 (1995), p. 390.

50. G. Cumming, 'French aid to Africa: towards a new consensus?', Modern and Contemporary France, NS4, 4 (1996), pp. 454-5.

51. R. Banégas and P. Quantin, 'Orientation and limitations of French aid for democratic development - Benin, Congo and the Central African republic', special issue of Canadian Journal of Development Studies (1996), pp. 113-33.

52. B. Hibou, 'Politique économique de la France en zone franc', Politique africaine 58 (1995), p. 36.

53. Bourmaud, 'La politique africaine de Jacques Chirac’, pp. 439-40. 
54. 'UK and France join forces for African mission', The Guardian, 2 January 2002, p. 5.

55. 'Allocution du Premier ministre devant la communauté française à Dakar (Sénégal)', 19 December 1997, www.defense.gouv.fr/actualites/dossier/d20/5_3.htm and 'Discours devant le Parlement sud-africain’, 31 May 2001, www.premier-ministre.gouv.fr [accessed 27 March 2002].

56. 'Hunting lobby', p. 6.

57. Smith and Glaser, Ces Messieurs Afrique 2, p. 25.

58. Smith and Glaser, Ces Messieurs Afrique 2, pp. 133-51 and F.-X. Verschave, Noir Silence, pp. 263-71.

59. Bourmaud, 'La politique africaine de Jacques Chirac', p. 435-6. 